\title{
Respiratory Effects of Exposure to Environmental Noise Levels and Noise Annoyance
}

\author{
Maria Foraster, PhD, MPharm, MPH
}

ISGlobal; Universitat Pompeu Fabra (UPF); CIBER Epidemiología y Salud Pública (CIBERESP); Blanquerna School of Health Science, Universitat Ramon Llull (URL). Barcelona, Spain

\section{ABSTRACT}

Environmental noise is a main stressor associated with several ailments. Some studies have also reported associations between noise and respiratory disease. The aim of this study is to perform a comprehensive review of the epidemiological evidence for the association of road, railway, aircraft, wind turbine and neighbourhood noise with respiratory disease. Articles from 1980 until August 25 $5^{\text {th }}, 2020$, were searched in PubMed and Scopus by one person. Several of the 15 included peer-reviewed articles suggested associations of short- or long-term exposure to noise or noise annoyance, particularly of road traffic noise, with respiratory morbidity or mortality, independently of air pollution. However, the evidence was rated as insufficient for the association between specific exposure and outcome couples, due to the few studies available for each pair and the remaining inconsistencies. To improve the evidence, further and better studies are needed that consider short- and long-term exposure to noise, mediation by annoyance, and adjustment for air pollution. (BRN Rev. 2021;7(1):4-26)

Corresponding author: Maria Foraster, maria.foraster@isglobal.org

Keywords: Noise. Respiratory. Road. Stress. Transportation. 


\section{INTRODUCTION}

Environmental noise is a main environmental stressor that has been investigated for decades. There is extensive evidence for the association of long-term exposure to transportation noise with noise annoyance ${ }^{1}$, sleep disturbance $^{2}$, and cardiovascular disease and mortality, as well as suggestive evidence for its association with obesity, diabetes ${ }^{3}$ and cognitive impairment ${ }^{4}$, independently of air pollution. Exposure to noise might also affect respiratory health ${ }^{5}$. However, this initially counterintuitive association has received less attention and only in recent years several new studies have addressed this issue again ${ }^{6-8}$.

The biological pathways for the multi-systemic effects of noise on health, including respiratory health, were reviewed in detail in Recio et al. (2016) ${ }^{5}$. The main suggested biological pathway is the stress response induced by noise, which relates both to psychological (i.e. noise annoyance) and physiological stress responses $^{9}$. Noise-induced stress triggers the autonomous nervous system, but also acts through the Hypothalamic-Pituitary-Adrenal Axis, with the release of glucocorticoids such as cortisol ${ }^{10}$. Moreover, night-time transportation noise leads to sleep disturbance ${ }^{2}$. As a consequence, insufficient night-time recovery and neuroendocrine stimulation could disrupt the response of the immune system in tissues, including the respiratory tract ${ }^{5}$. The stress hypothesis is supported by the accumulated evidence on the association between acute and chronic stress and respiratory diseases and exacerbations ${ }^{11-14}$.

In conclusion, it is suggested that short- and/ or long-term exposure to environmental noise sources could lead to psychological and physiological stress reactions that could contribute to acute and chronic respiratory problems or exacerbations of respiratory diseases. This would increase the already high burden of disease related to environmental noise, which is estimated to be the second most important environmental health hazard in Europe, just after air pollution ${ }^{15}$. Given the public health concern and recent increase in publications in this field, an extensive review is needed to understand the state of the field and its evolution over time. The aim of this study is to perform a comprehensive review of the existing epidemiological peer-reviewed evidence about the association between human exposure to environmental noise and respiratory health and mortality.

\section{METHODS}

\section{Design}

The review process was guided by the general principles of the Preferred Reporting Items for Systematic review and Meta-Analysis Protocols (PRISMA-P). The conceptual diagram of the review is shown in figure 1.

\section{Eligibility criteria}

The current review included: i) systematic reviews with meta-analyses and original individual peer-reviewed epidemiological studies of the last 40 years, from January 1980 until August $25^{\text {th }}, 2020$; ii) participants of all ages, biological sex, and countries, with or without health conditions; iii) studies published in English, French, Spanish, German, Italian, and 


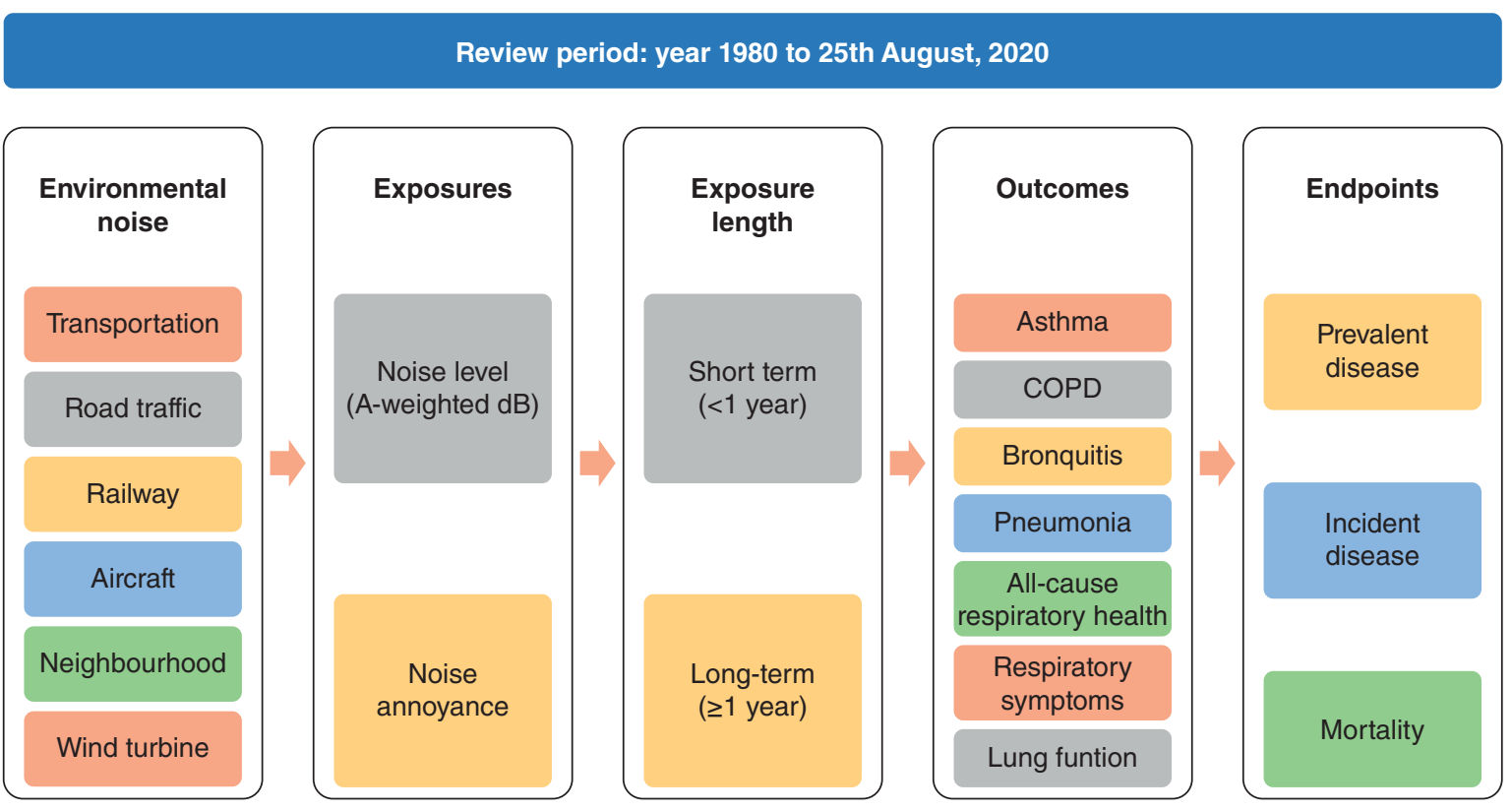

Figure 1. Conceptual diagram of the review.

COPD: chronic obstructive pulmonary disease.

Portuguese; iv) studies assessing either shortor long-term exposure to common environmental noise levels and sources (road, railway, aircraft, wind turbine noise and neighbourhood noise); v) studies assessing noise annoyance to the previously mentioned environmental sources; and vi) studies assessing outcomes of respiratory health, including respiratory symptoms, self-reported and doctor-diagnosed respiratory diseases, and registry-based respiratory causes of hospital admission and mortality.

Exclusion criteria were: i) self-reported exposure to noise levels; ii) noise produced in hospitals; iii) occupational noise; iv) exposure to high noise levels not corresponding to environmental noise levels; v) studies in animals; and vi) institutionalized participants.

\section{Search}

The same searches were performed in two different electronic databases: PubMed and Scopus. The search strategy combined the following terms and related Medical Subject Headings (MeSH) in the title or abstracts of articles: "noise", "sound", "road", "railway", "aircraft", "exposome", "respiratory", "respirat", "asthma", "COPD", "lung", "asthma", "pneumonia", "chest", and/or wheez". 


\section{Selection and data extraction}

Screening, eligibility and data extraction was carried out by the only author. Reviews and individual studies assessing the association between exposure to noise and respiratory health were preselected based on the title and abstract in Mendeley. The full text of the preselected reviews and individual articles was screened for final eligibility of the studies. The next data was extracted in a structured data extraction form: publication details, setting, population characteristics, sample size, study period, design, exposure (type, method), outcome (type, method), and main results. No prioritization of exposures or outcomes was necessary due to the limited number of eligible studies.

\section{Data aggregation and assessment of the evidence}

Due to the small number of studies (less than five) for each exposure-outcome couple of similar definitions, no meta-analysis could be performed. The degree of evidence for an association was assessed qualitatively based on the consistency across multiple studies, and in light of the quality of the study designs and their main limitations. The next terms were used to summarize the evidence: a) "Strong evidence" of an association based on consistent results from multiple studies and meta-analyses, b) "Moderate evidence" of an association based on multiple studies, but with some inconsistencies, c) "Insufficient evidence" of an association based on only a few studies, or with substantial inconsistencies, and d) No evidence (no studies).

\section{RESULTS}

A total of 703 articles were identified, 444 in PubMed, 256 in Scopus and 3 additional records in the references of the reviews and individual studies (see figure 2). The removal of duplicates reduced the number of studies to 434. After screening the title and abstracts, a total of 365 studies were excluded. After screening the remaining 70 full-text articles, 55 were excluded for the next reasons: review, editorial or letter $(n=16)$, health impact assessment study $(n=2)$, hospital noise study $(n=3)$, no direct association tested between the exposure and outcomes of interest, or no respiratory disease outcome $(\mathrm{n}=17)$, occupational noise study $(\mathrm{n}=7)$, no noise exposure $(n=2)$, self-reported exposure $(\mathrm{n}=3)$, animal studies, which had in addition non-eligible exposure or outcome $(n=2)$, text not found $(n=2)$. A total of 15 articles were finally included for qualitative assessment, corresponding to individual peer-reviewed studies. No systematic reviews with meta-analyses were available. Figure 3 shows the temporal distribution of the eligible publications and their final inclusion in the review.

The characteristics of the 15 included studies are summarized in Table 1 and the quantitative results are reported in Table 2. Among the 15 included studies, 4 studies corresponding to the same city (Madrid, Spain) for different time periods and outcomes, studied the association between short-term exposure to road traffic noise based on daily measurements of the urban network of monitoring stations, which increased from 6 stations in the first studies ${ }^{16,17}$ to 26 in the latest $^{8.18}$. The remaining 11 studies evaluated 


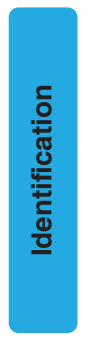

Records identified through database searching $(n=700)$
Records after duplicates removed $(n=434)$
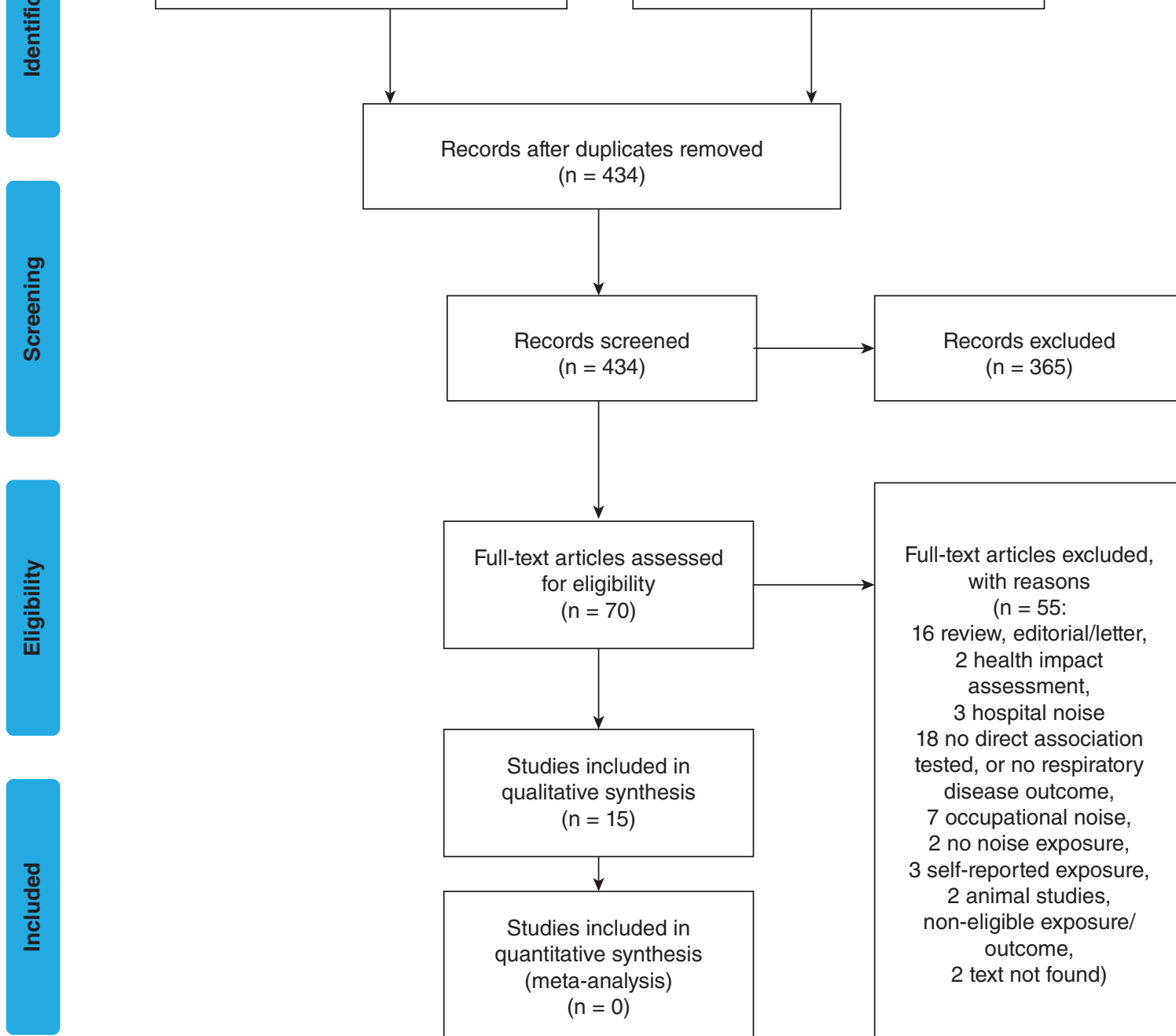

Studies included in qualitative synthesis $(n=15)$

Studies included in quantitative synthesis (meta-analysis) $(\mathrm{n}=0)$

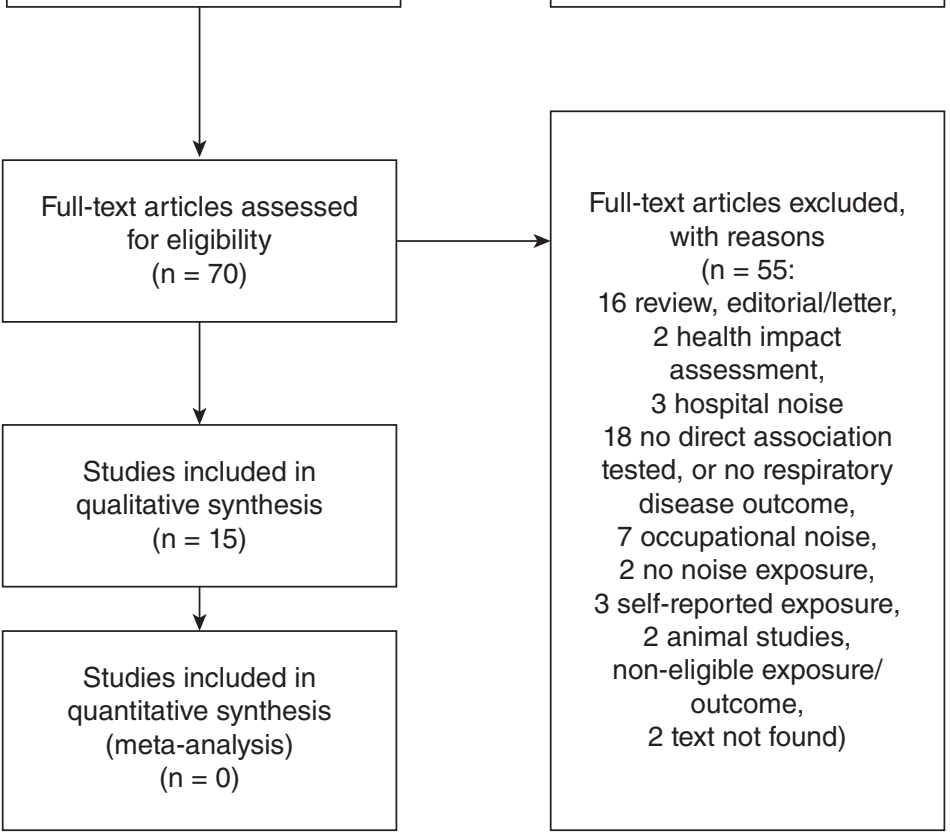

Additional records identified through other sources $(n=3)$

Figure 2. Flow chart of the search and included studies (adapted from Moher $D$ et al. ${ }^{32}$ with permission).

A-weighted equivalent noise levels of longterm residential exposure to noise (mostly Lden, i.e. the day-evening-night EU noise indicator, unless otherwise specified), which were assessed either with measurements or standard modelling techniques; and/or noise annoyance, which was assessed with International Commission on Biological Effects of Noise (ICBEN) or ICBEN-like 5-point or 11-point Likert scales. Road traffic noise level was the exposure most commonly studied $(\mathrm{n}=12)^{6-8,10,16-24}$. 


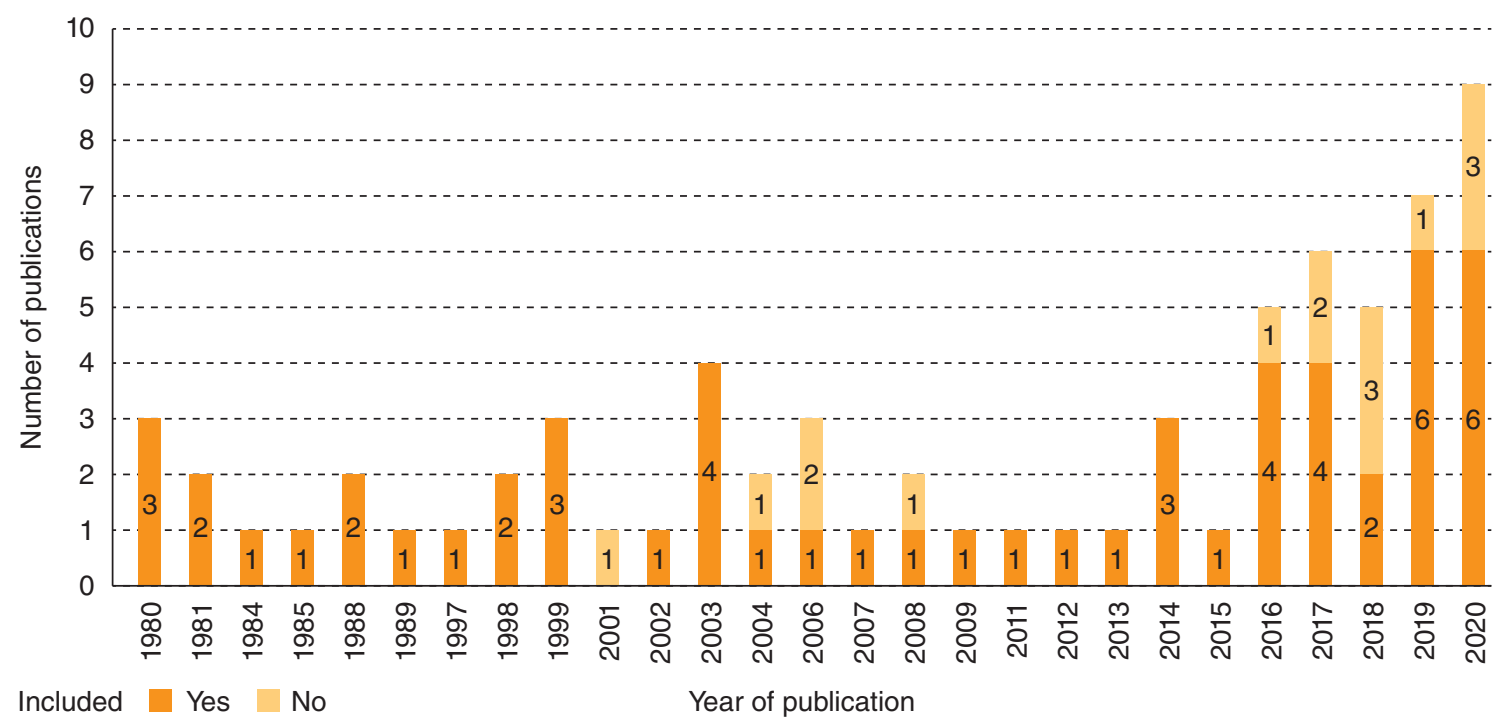

Figure 3. Number of publications assessed for eligibility by year of publication and final inclusion in the review.

\section{Asthma}

A total of five studies evaluated prevalent asthma, as self-reported ${ }^{20}$ or self-reported doctor-diagnosed asthma6,23,25,26. A total of 3 studies examined incident self-reported ${ }^{20}$ or self-reported doctor-diagnosed asthma ${ }^{6,23}$. One article studied asthma mortality based on mortality records (International Coding of Diseases 10, ICD-10: J45-J46) ${ }^{8}$.

\section{NOISE LEVELS}

In general, no associations were observed between exposure to road traffic noise levels and asthma prevalence or incidence in children $(n=1)^{23}$, adults $(n=2)^{6,20}$, or mortality $(\mathrm{n}=1)^{8}$. Short-term exposure to road traffic was not related to register-based asthma mortality, between years 2003 to 2009 in a case-crossover study in Madrid, Spain ${ }^{8}$. Prevalent or incident asthma were not associated with long-term exposure to road traffic noise neither in a cohort that assessed pre- and post-natal exposure from childhood to adolescence in Sweden $(n=4000)^{23}$, or in a cross-sectional study of three European adult cohorts $(n=646,731)^{20}$, nor for transportation noise or its sources (road, railway and aircraft noise) in a repeated-measures cohort of adults in Switzerland including 17138 observations and 7049 participants $^{6}$. In the latter study though, transportation noise was associated with asthma symptoms (wheezing symptoms, chest tightness, and dyspnoea after exercise), as well as with current asthma among asthmatics, especially in those reporting adult-onset asthma [(odds ratio [OR] of Lden: 1.90 (95\% confidence interval [CI]: 1.25, 2.89) per $10 \mathrm{~dB}$; p-value of interaction (adult-onset versus childhood-onset) $=0.03$. 


\section{NOISE ANNOYANCE}

A total of three studies explored noise annoyance in relationship with asthma ${ }^{6,25,26}$. The repeated-measures Swiss cohort study reported an association between being annoyed by transportation noise and increased asthma symptoms and current asthma (but not incident asthma) ${ }^{6}$. These associations were independent of exposure to the objective noise level and air pollution. Moreover, in a crosssectional study in 12-year old children ${ }^{26}$, there was increased prevalence of asthma among girls $(n=316)$, but not in boys $(n=336)$, who reported greater total noise annoyance at night (OR: 1.5, 95\% CI: 1.1; 2.1), noise annoyance within the home/apartment (OR: 3.5, $95 \%$ CI: $1.5 ; 8.0)$, or noise annoyance in or around the house (OR: 3.3, 95\% CI: 1.7; 6.3). Models were not adjusted for air pollution. Finally, a population-based survey supported by the World Health Organization (WHO) in 8 European cities $(n=8539)$ found no association between neighbourhood noise or transportation noise annoyance and prevalent asthma in children or adults ${ }^{25}$.

Although the studies, including two cohort studies, suggest no association between exposure level to transportation noise (mainly road traffic) and asthma morbidity or mortality, more asthma symptoms and current asthma were observed among asthmatics. In turn, studies evaluating transportation and other home-related noise annoyance suggest some associations with prevalent asthma. Overall, the evidence is limited to few populations of different ages, therefore the degree of evidence for an association between environmental noise and asthma was rated as insufficient.

\section{Chronic obstructive pulmonary disease}

The current review identified one study on long-term exposure to road traffic and railway noise with chronic obstructive pulmonary disease (COPD) mortality registers in a large cohort study (ICD-10: J40-44) ${ }^{7}$ and two on short-term exposure to road traffic noise, either with attended emergency medical calls ${ }^{18}$ or COPD mortality registers (in both cases using ICD-10 codes: J40-44, J47) ${ }^{8}$. The large adult cohort in the Netherlands $(n=339,633)^{7}$ did not find an association between individual longterm exposure to road traffic noise, hazard ratio (HR) $(95 \% \mathrm{CI}): 0.98(0.91$; 1.05) per interquartile range (IQR) in Lden levels $(7.40 \mathrm{~dB})$, or railway noise, HR (95\% CI): $1.03(0.96 ; 1.10)$ per IQR in Lden levels $(8.60 \mathrm{~dB})$, and COPD mortality. In contrast, short-term exposure to maximum night-time road traffic noise levels assessed in 26 noise monitoring stations in Madrid, Spain, was associated with increased COPD mortality the day after in people over 64 years of age between years 2003 and 20098: relative risk (RR) of 1.040 (95\% CI: 1.010; 1.070) per $1 \mathrm{~dB}$. Moreover, another study in Madrid using the same exposure assessment found that short-term exposure to average night-time road traffic noise levels was associated with COPD emergency medical calls in adults in lags 0 and 1, between January 2008 and December 200918: RR of 1.15 (95\% CI: 1.09; 1.21) per $1 \mathrm{~dB}$. None of the two previous studies in Madrid found associations with average daytime noise levels. All studies adjusted for relevant confounders, including traffic-related air pollution.

Despite the large longitudinal study and the suggestive short-term associations in Madrid, 
only one population has been studied for both the short- and long-term effects of noise. In summary, the evidence for the association of exposure to road traffic noise and railway noise with COPD is still insufficient. No evidence exists for other environmental noise sources.

\section{Bronchitis and pneumonia}

\section{NoISE LEVELS}

A total of two studies aimed to study bronchitis, both in children, one in relation to long-term exposure ${ }^{10}$ and another one with short-term exposure to road traffic noise ${ }^{17}$. Three studies from Madrid (Spain) also studied short-term exposure to road traffic noise in relation with pneumonia ${ }^{8,17,18}$. In a crosssectional study of 68 children in Germany, Ising et al. ${ }^{10}$ (2004) reported a dose-dependent association of combined exposure to road traffic noise and nitrogen dioxide levels, measured for many days at the children's bedrooms at night, with greater annual physician contacts due to bronchitis. Noise and air pollution effects could not be addressed independently due to the high correlation between the two factors, which was driven by the proximity of the houses to a road with heavy traffic.

The Madrid time series study (years 1995 to 2000) in children of 0 to 9 years of age reported an association between short-term exposure to road traffic noise assessed in 6 monitoring stations and pneumonia hospital admissions (ICD-9: 480-487) [RR (95\% CI): $1.08(1.02$; 1.15) per $1 \mathrm{~dB}$ ] but not bronchitis (ICD-9: 460-496) three days after exposure ${ }^{17}$.
Later on, another time series study in Madrid between January 2008 and 2009, now including 26 urban background noise monitors, found that short-term exposure to night-time road traffic noise was associated with attended emergency medical calls due to pneumonia (ICD-10: J12-J18) the same day: $\mathrm{RR}=1.17$ (95\% CI: 1.09 ; 1.25) per $1 \mathrm{~dB}$, independently of air pollution and temperature ${ }^{18}$. In addition, for the period between 2003 and 2009, the case-crossover study in the same study area and also including 26 noise monitors, observed a relationship between short-term exposure only to the maximum peak road traffic noise levels at night and register-based pneumonia mortality (ICD-10: J12-J18) one day after for patients over 64 years of age and only when Nitrogen Dioxide $\left(\mathrm{NO}_{2}\right)$ was greater than $30 \mathrm{mcg} / \mathrm{m}^{3}$, and independently of air pollution and temperature and relative humidity ${ }^{8}$.

\section{NoISE ANNOYANCE}

Only the population-based survey supported by the WHO in eight European cities $(n=8539)$ studied noise annoyance and bronchitis and found associations of both severe and chronic neighbourhood or transportation noise annoyance with prevalence of self-reported doctor-diagnosed bronchitis in children and adults, but not in the elderly ${ }^{25}$.

Due to the limited number of studies for each population group, exposure and setting, and the inconsistencies across results in children and methodologies used, the evidence was rated as insufficient for an association of transportation and neighbourhood noise with bronchitis or pneumonia. 


\section{All-cause respiratory disease and mortality}

Three studies assessed register-based respiratory mortality (ICD-10: J00-J99), two in relation to long-term exposure to road traffic noise $\mathrm{e}^{7,22}$ and one in relation to short-term exposure $^{8}$. None of the two large adult cohorts in the Netherlands $(\mathrm{n}=339,633)^{7}$ and Denmark $(n=52,758)^{22}$ assessing individual longterm exposure to road traffic noise reported associations with respiratory disease mortality obtained from mortality registers, independently of air pollution. In contrast, in a case-crossover study in Madrid (Spain) between 2003 and 2009, short-term exposure to night-time road traffic noise assessed in 26 noise monitoring stations was associated with increased register-based respiratory mortality one day after exposure in people over 64 years of age only when $\mathrm{NO}_{2}$ levels were above $30 \mathrm{mcg} / \mathrm{m}^{38}$. This study controlled for time-varying confounders such as air pollutants $\left(\mathrm{NO}_{2}\right.$, particulate matter of $2.5 \mu \mathrm{m}$ of aerodynamic diameter, temperature and relative humidity).

Regarding respiratory morbidity, one study explored long-term exposure to road traffic noise and three studies in the same city (Madrid) evaluated short-term exposure to road traffic noise. A Dutch study evaluating several social and environmental factors in single-pollutant models found no relationship between long-term neighbourhood-level road traffic noise or railway noise ( $\mathrm{n}=135$ neighbourhoods) and prevalent respiratory disease defined as asthma or COPD obtained from registers ((Dutch) ICPC-1 system codes R91, R95, R96) of 4450 inhabitants representative of the Netherlands ${ }^{24}$. Short-term exposure to road traffic noise assessed in six monitoring stations in Madrid, Spain, was associated with respiratory hospital admissions (ICD-9 460-459) in adults the same day in a time series study covering years 1995 to $1997^{16}$, and with respiratory hospital admissions (ICD-9: 144; 460-519) in children between 0 to 9 years of age, three days after exposure, in a time series study covering the years 1995 to $2000^{17}$. The latter did not adjust for air pollution due to collinearity. In a further study between January 2008 and 2009 in Madrid, including 26 urban background noise monitors, short-term exposure to night-time road traffic noise was associated with the number of emergency medical calls taken care of due to respiratory causes (ICD-10: J00-J99) the same day: RR (95\% CI): 1.14 (1.11; 1.18) per $1 \mathrm{~dB}^{18}$.

Overall, despite the two large longitudinal studies, the evidence is limited to few populations of different ages for each exposure window and outcome and some studies used ecological approaches that require further confirmation. Therefore, the degree of evidence for an association between road traffic and railway noise and respiratory morbidity or mortality was rated as insufficient. There is no evidence for other environmental noise sources.

\section{Respiratory symptoms}

Respiratory symptoms were assessed in four studies in relationship to long-term exposure to transportation noise levels (i.e., road, railway or aircraft) and/or noise annoyance at home: 
- A birth cohort in Sweden $(n=4000)$ reported no association between pre- or post-natal long-term exposure to road traffic noise and prevalent or incident wheezing in childhood until 16 years of age. This study defined wheezing as at least one self-reported period of wheeze during the last 12 months or first-time wheeze ever, respectively, and adjusted for age, sex, individual socioeconomic status and air pollution ${ }^{23}$.

- A Dutch adult cohort with a follow-up of three years ${ }^{19}$ assessed respiratory symptoms with items from the European Community Respiratory Health Survey II and derived a score (score 0-5) as the sum of five items ${ }^{27}$. This study found that longterm exposure to road traffic noise, objectively assessed through standard modelling at the residential address, was linked to a higher score of current respiratory symptoms in mixed models accounting for baseline $(\mathrm{n}=14829)$ and follow-up ( $n=7905$, year 2015) visits, without adjustment for air pollution. The estimated effect disappeared after adjustment for the self-reported (i.e., perceived) noise level (correlation between modelled and perceived noise level was $r=0.40$ ). Moreover, the perceived noise level was associated with current and changes in respiratory symptoms between visits, independently of the objectively modelled noise level. Perception of noise levels and perception of air pollution levels were highly correlated $(r=0.76)$ and mutual adjustment was not performed. It should be noted that perception of the noise level in this study was not a measure of noise annoyance but rather a self-reported measure of the noise level according to the question wording "To what extent are you exposed to [name of the exposure]" in a 7-point Likert scale. Therefore, this specific indicator of perception was not eligible in the current review.

- The Swiss adult cohort studied the following nine individual current respiratory symptoms: regular cough/phlegm, chronic cough/phlegm, wheezing, wheezing without cold, wheezing with dyspnoea, chest tightness, nocturnal dyspnoea causing persons to wake up, diurnal dyspnoea at rest and dyspnoea after exercise $^{6}$. These symptoms were all consistently associated with transportation noise annoyance, and some of them were only associated with long-term exposure to transportation noise among asthmatic participants. Models were mutually adjusted for noise levels and annoyance and air pollution.

- Finally, the population-based survey supported by the WHO in eight European cities $(n=8539)$ reported dose-dependent associations with prevalence of overall self-reported respiratory symptoms for severe and chronic neighbourhood or transportation noise annoyance in children and for severe and chronic transportation noise annoyance in adults, but not in the elderly ${ }^{25}$.

In summary, results regarding exposure to long-term road traffic noise and respiratory symptoms are inconsistent and only based on three studies, one of them in children, and one of them not adjusting for air pollution. Besides, the studies on noise annoyance suggested consistent associations between 
transportation noise and respiratory symptoms. Although both studies had large sample sizes (one of them with three repeated measurements), these results were cross-sectional and based only on two studies. Overall, the evidence is still insufficient for the association between transportation noise and respiratory symptoms. Because only one study assessed neighbourhood noise annoyance, the evidence is also insufficient for the association between neighbourhood noise and respiratory symptoms.

\section{Lung function}

One study of the European Human Early-Life Exposome (HELIX) cohort assessed the association of multiple prenatal and postnatal exposures, including road traffic noise, with forced expiratory volume in one second percent predicted values $\left(\mathrm{FEV}_{1} \%\right)$ in children of age 6 to 12 years born between 2003 and 2009 . The sample consisted of 1033 mother-child pairs of cohorts in France, Greece, Lithuania, Norway, Spain, and the UK and $70-71 \%$ of the sample had information on road traffic noise indicators. Exposure to residential and/or school-level road traffic noise (Lden and/or Lnight) was heterogeneously assessed across countries, with standard EU noise maps or measurements, and it was generally analysed in 4 categories (Lden: $<55,55-60,60-65,>65 \mathrm{~dB}$; Lnight: <57; 57-67; 67-71; > $71 \mathrm{~dB}$ ). After multiple imputation of missing values, no association was observed between any road traffic noise indicator and lung function.

Overall, as only one study was identified, the evidence for the association between road traffic noise and lung function symptoms was rated as insufficient. No evidence exists for the rest of noise exposures.

\section{DISCUSSION}

The current review has analysed the existing epidemiological evidence regarding the association between exposure to short- and longterm environmental noise (road, railway, aircraft, wind turbine noise and neighbourhood noise), both in terms of the objective noise level and noise annoyance, on a wide range of respiratory health outcomes since year 1980. The current review has found that, overall, there are indications of an association between environmental noise (both the noise level and annoyance), particularly road traffic noise, and adverse respiratory health effects, independently of air pollution. However, the degree of evidence for the association between specific environmental noise sources and specific acute or chronic respiratory adverse effects is still insufficient due to the small number of studies and settings in which each relationship has been tested, either in children or adults. Further and high-quality studies are needed to confirm current findings and to better understand how noise affects the respiratory system.

Although the epidemiological evidence is still insufficient, the effects of environmental noise on respiratory health are biologically plausible, as summarized by Recio et al. $(2016)^{5}$. The main hypothesized pathway considers that noise is a stressor and that there is mounting evidence that acute and chronic stress relates to respiratory diseases ${ }^{11,12}$ and more symptoms in asthmatics ${ }^{13,14}$. Noise leads to psychological stress responses (i.e. noise 
annoyance) but also to physiological stress responses even without experiencing noise annoyance ${ }^{9,28}$. As a stressor, noise has the capacity to trigger the autonomic nervous system and endocrine system, with the release of catecholamines and also glucocorticoids such as cortisol, as observed in several field and experimental studies ${ }^{29,30}$, including one of the studies in the current review, which reported greater saliva cortisol concentrations in children exposed to night-time road traffic noise ${ }^{10}$. Moreover, night-time transportation noise affects sleep ${ }^{2}$. Taken together, insufficient recovery at night and neuroendocrine activation may alter the immune system and lead to proinflammatory responses in tissues, including the respiratory tract ${ }^{5}$.

The few studies identified in the current review might suggest that noise has both shortterm and long-term effects on the respiratory system and that effects may be partially driven by noise annoyance through a psychological stress reaction. It should be noted though that disentangling short- and long-term effects could be challenging due to the possible co-existence of both effects in the development of disease, exacerbations or even fatality, and due to the need to carefully account for the possible high correlation of noise levels within regular weekdays, particularly in settings highly dominated by road traffic noise with controlled meteorological conditions, in which measurements as short as 15-min are highly representative of the longterm average noise levels in the same location (ISO 1996-2:2017).

The current evidence is still insufficient to derive conclusions about the most relevant time window of exposure and the role of noise annoyance. Although short-term exposure to noise was rather consistently associated with respiratory disease emergencies and mortality in several time series ${ }^{16-18}$ and a case-crossover study ${ }^{8}$, all of the studies were performed in the same city (Madrid, Spain), and some used only six noise monitoring stations ${ }^{8,16}$, which could lead to greater ecological bias. Moreover, the authors of the case-crossover study acknowledged that models for respiratory mortality were temporally unstable and that further time-series studies with new time-periods were needed ${ }^{8}$. Besides, results on long-term exposure to transportation noise were mixed, with the few but large longitudinal studies for each exposure-outcome pair generally suggesting null associations either with COPD, asthma, lung function, or all-cause respiratory mortality in children or adults $6,7,20-23$ and cross-sectional analyses suggesting either no association, or indications of associations with respiratory problems ${ }^{10,19,23}$ or associations only in asthmatics ${ }^{6}$. These inconsistencies may be caused by the use of different follow-up periods, some of them as short as three years ${ }^{7}$, or the quality of the exposure and outcome assessment, the low statistical power in incident analyses ${ }^{6}$, or the ability to adjust for air pollution ${ }^{10,19}$, among others. In contrast, studies analysing noise annoyance in the last 12 months (a measure of longer-term noise annoyance) found consistent associations with prevalent respiratory problems and asthma ${ }^{6,25,26}$, but not incident asthma, which could suggest a mediation role by noise annoyance, but should be confirmed with proper mediation analyses and additional prospective assessments also to discard reverse causality and limit information bias. 
Among the previous potential causes explaining inconsistencies, the quality of the noise exposure assessment deserves special discussion. Noise is a very local phenomenon affected by shielding elements. High-resolution, accurate, and individual assessment methods, such as the source-specific models used by Eze et al. $(2019)^{6}$, are needed to avoid exposure misclassification and biased findings, including dilution of estimated effects. Some studies assign source-specific noise exposure (Lden, Lnight) directly from European noise map layers, which in turn are only available for agglomerations above 100,000 inhabitants. EU noise maps vary in resolution and reliability depending on the methods used to derive the estimates and their final layout. Moreover, low-resolution models or EU noise maps may not provide data or accurate data for low noise levels (below $55 \mathrm{~dB}$ ), which are also relevant for health ${ }^{15}$, and due to their low resolution they might be summarized in few exposure categories. This may limit the statistical power, exposure contrast, and the likelihood to detect associations. This could have been the case, for example, in the HELIX study ${ }^{21}$, or in the study by Cai et al. $(2017)^{20}$, although the latter had a very large sample size which might partly compensate the potential exposure missclassification. Finally, studies assessing exposure to noise with measurements should use standard protocols to provide reliable indicators, and they should state their ability to differentiate total noise from its main sources. For example, in the time series studies from Madrid, the background monitoring stations measured total noise, but it was assumed that measurements represented road traffic noise, because almost $80 \%$ of the environmental noise in Madrid is due to traffic ${ }^{8,17}$.
An important advancement in many of the available studies of road traffic noise and respiratory health is the adjustment for traffic-related air pollution, which is one of the main confounders given the known effects of traffic-related air pollution on respiratory morbidity and mortality. Although both noise and air pollution have plausible independent effects and this is acknowledged $^{31,32}$, e.g., for cardiovascular disease, this does not exempt epidemiological studies from adjustment in order to yield unbiased magnitudes of effect, particularly in areas in which co-exposure to noise and air pollution is frequent $^{32}$.

This review had some limitations. Despite being guided by standard protocols for systematic reviews, only one person assessed the existing evidence, which could have led to random or systematic errors in the selection and assessment of the articles. To reduce the extent of this potential error, the process was reviewed twice by the same person. Moreover, given the early stage of the research field and the limited number of studies available for each exposure and outcome pair, the review only provided a general qualitative assessment of the evidence to inform future research, and it did not include a formal assessment of the risk of bias of each individual study. Finally, for the same reason, no meta-analyses could be conducted. The main strengths of the current study include the comprehensive review of the literature by searching the evidence since 1980, the assessment of both the physiological and psychological stress reactions to noise through the assessment of exposure to the objective noise levels and of the assessment of the individual noise 
annoyance, and the wide range of noise sources, beyond road traffic noise, as well as of exposure windows, including both shortand long-term exposure.

In conclusion, the evidence is still insufficient to determine the association between exposure to specific environmental noise sources (road, railway, aircraft, wind turbine noise and neighbourhood noise) and specific respiratory health outcomes, due to the small number of studies available that assess each relationship and some inconsistencies in results or methodological limitations. Nevertheless, the current evidence suggests an overall potential association between environmental noise and adverse respiratory health effects, particularly for road traffic noise levels and annoyance, and independently of air pollution. Due to the public health relevance of the potential effect of environmental noise on the respiratory system, there is a need for more and better studies, which consider both short- and long-term exposure to noise as well as the mediatory role of noise annoyance and adjustment for air pollution.

\section{DISCLOSURES}

Dr. Foraster has nothing to disclose.

\section{ACKNOWLEDGMENTS}

Maria Foraster has received funding from the Beatriu de Pinós programme of the Government of Catalonia's Secretariat for Universities and Research of the Ministry of Economy and Knowledge during the preparation of this review.

\section{REFERENCES}

1. Guski R, Schreckenberg D, Schuemer R. WHO Environmental Noise Guidelines for the European Region: A Systematic Review on Environmental Noise and Annoyance. Int J Environ Res Public Health. 2018 Mar; 15(3): 519. Basner M, McGuire S. WHO environmental noise guidelines for the European region: A systematic review on environmental noise and effects on sleep. Int J Environ Res Public Health. 2018;15: 519..

2. Kempen E van, Casas M, Pershagen G, Foraster M. WHO Environmental Noise Guidelines for the European Region: A Systematic Review on Environmental Noise and Cardiovascular and Metabolic Effects: A Summary. Int J Environ Res Public Health. 2018;15: 379.

3. Clark C, Paunovic K. WHO Environmental Noise Guidelines for the European Region: A Systematic Review on Environmental Noise and Cognition. Int J Environ Res Public Health. 2018;15:285.

4. Recio A, Linares C, Banegas JR, Díaz J. Road traffic noise effects on cardiovascular, respiratory, and metabolic health: An integrative model of biological mechanisms. Environ Res. 2016;146:359-70.

5. Eze IC, Foraster M, Schaffner E et al. Transportation noise exposure, noise annoyance and respiratory health in adults: A repeated-measures study. Environ Int. 2018;121:741-50.

6. Klompmaker JO, Hoek G, Bloemsma LD et al. Surrounding green, air pollution, traffic noise exposure and non-accidental and cause-specific mortality. Environ Int. 2020;134:105341.

7. Recio A, Linares C, Banegas JR, Díaz J. The short-term association of road traffic noise with cardiovascular, respiratory, and diabetes-related mortality. Environ Res. 2016;150:383-90.

8. Westman JC, Walters JR. Noise and stress: A comprehensive approach. Environ Health Perspect. 1981;41:291-309.

9. Ising H, Lange-Asschenfeldt H, Moriske H-J, Born J, Eilts M. Low frequency noise and stress: bronchitis and cortisol in children exposed chronically to traffic noise and exhaust fumes. Noise Health. 2004;6:21-8.

10. Korkeila J, Lietzen R, Sillanmäki LH, Rautava P, Korkeila K, Kivimäki M, et al. Childhood adversities and adult-onset asthma: A cohort study. BMJ Open. 2012;2:e001625.

11. Rod NH, Kristensen TS, Lange P, Prescott E, Diderichsen F. Perceived stress and risk of adult-onset asthma and other atopic disorders: A longitudinal cohort study. Allergy Eur J Allergy Clin Immunol. 2012;67:1408-14.

12. Chen E, Miller GE. Stress and inflammation in exacerbations of asthma. Brain, Behavior, and Immun. 2007;21:993-9.

13. Wright RJ. Epidemiology of Stress and Asthma: From Constricting Communities and Fragile Families to Epigenetics. Vol. 31, Immunol Allergy Clin North Am. 2011;31:19-39.

14. WHO Regional Office for Europe. Environmental Noise Guidelines for the European Region (2018). Copenhagen: World Health Organization; 2018, Oct.

15. Tobias A, Díaz J, Saez M, Alberdi JC. Use of poisson regression and box-jenkins models to evaluate the short-term effects of environmental noise levels on daily emergency admissions in Madrid, Spain. Eur J Epidemiol. 2001; 17:765-71.

16. Linares C, Díaz J, Tobías A, De Miguel JM, Otero A. Impact of urban air pollutants and noise levels over daily hospital admissions in children in Madrid: a time series analysis. Int Arch Occup Environ Health. 2006;79: $143-52$.

17. Carmona R, Linares C, Ortiz C, Vázquez B, Díaz J. Effects of noise on telephone calls to the Madrid Regional Medical Emergency Service (SUMMA 112). Environ Res. 2017;152:120-7.

18. Martens AL, Reedijk M, Smid T et al. Modeled and perceived RF-EMF, noise and air pollution and symptoms in a population cohort. Is perception key in predicting symptoms? Sci Total Environ. 2018;639:75-83. 
19. Cai Y, Zijlema WL, Doiron D et al. Ambient air pollution, traffic noise and adult asthma prevalence: a BioSHaRE approach. Eur Respir J. $2017 ; ; 49$.

20. Agier L, Basagaña X, Maitre L et al. Early-life exposome and lung function in children in Europe: an analysis of data from the longitudinal, population-based HELIX cohort. Lancet Planet Health. 2019;3:e81-92.

21. Thacher JD, Hvidtfeldt UA, Poulsen AHet al. Long-term residential road traffic noise and mortality in a Danish cohort. Environ Res. 2020;187:109633.

22. Wallas AE, Eriksson C, Ögren $M$ et al. Noise exposure and childhood asthma up to adolescence. Environ Res. 2020;185:109404.

23. Zock J-P, Verheij R, Helbich Met al. The impact of social capital, land use, air pollution and noise on individual morbidity in Dutch neighbourhoods. Environ Int. 2018;121:453-60.

24. Niemann H, Bonnefoy X, Braubach $\mathrm{M}$ et al. Noise-induced annoyance and morbidity results from the pan-European LARES study. Noise Health. 2006;8:63-79.

25. Bockelbrink A, Willich SN, Dirzus I et al. Environmental noise and asthma in children: sex-specific differences. J Asthma. 2008;45:770-3.
26. Sunyer J, Pekkanen J, Garcia-Esteban Ret al. Asthma score: predictive ability and risk factors. Allergy. 2007;62:142-8.

27. Babisch W. The Noise/Stress Concept, Risk Assessment and Research Needs. Noise Health. 2002;4:1-11.

28. Babisch W. Stress hormones in the research on cardiovascular effects of noise. Noise Health. 2003;5:1-11.

29. Schmidt FP, Basner M, Kröger G et al. Effect of nighttime aircraft noise exposure on endothelial function and stress hormone release in healthy adults. Eur Heart J. 2013;34:3508-14.

30. Tétreault LF, Perron S, Smargiassi A. Cardiovascular health, traffic-related air pollution and noise: Are associations mutually confounded? A systematic review. Int J Public Health. 2013;58:649-66.

31. Foraster M. Is it traffic-related air pollution or road traffic noise, or both? Key questions not yet settled! Int J Public Health. 2013;58:647-8.

32. Moher D, Liberati A, Tetzlaff J, Altman DG, The PRISMA Group (2009). Preferred Reporting Items for Systematic Reviews and Meta-Analyses: The PRISMA Statement. PLoS Med. 2009; 6:e1000097. 
TABLE 1. Main characteristics of the selected studies $(n=15)$

\begin{tabular}{|c|c|c|c|c|c|c|c|c|c|c|}
\hline $\begin{array}{l}\text { Refe- } \\
\text { rence }\end{array}$ & Source & $\begin{array}{c}\text { Exposure } \\
\text { length }\end{array}$ & Exposure assessment & Outcome & $\begin{array}{c}\text { Outcome } \\
\text { assessment }\end{array}$ & Design & $\mathbf{N}$ & Age & Study area & $\begin{array}{l}\text { Study } \\
\text { period }\end{array}$ \\
\hline (16) & Road traffic & Short-term & $\begin{array}{l}\text { Aggregated daily averages at } \\
6 \text { measurement monitoring stations } \\
\text { of noise in Madrid, Leq24h, Lday } \\
(8-22 \mathrm{~h}) \text {, Lnight (22-8h). }\end{array}$ & $\begin{array}{l}\text { Respiratory causes (hospital } \\
\text { admission). ICD-9 460-459 }\end{array}$ & Register & Time series & $\begin{array}{l}\text { Exposure in } \\
6 \text { locations, } 1096 \\
\text { observations }\end{array}$ & Adults & Madrid & 1995-1997 \\
\hline (10) & Traffic emissions & Long-term & $\begin{array}{l}\text { Combined "traffic emissions" based on } \\
\text { individually measured Lnight noise and } \\
\text { nitrogen dioxide (Palmes tubes) outside } \\
\text { the child's bedroom for several days, } \\
\text { children living close to a road with } \\
\text { frequent night-time heavy traffic } \\
\text { (lorries) }\end{array}$ & Bronchitis (prevalence) & Doctor-diagnosed & $\begin{array}{l}\text { Cross-sec- } \\
\text { tional }\end{array}$ & 68 & Children & Germany & 2004 \\
\hline (25) & $\begin{array}{l}\text { Neigh-bourhood } \\
\text { annoy:; } \\
\text { Transportation } \\
\text { annoy. }\end{array}$ & Long-term & $\begin{array}{l}\text { ICBEN 5-point source-specific noise } \\
\text { annoyance: general neighbourhood } \\
\text { noise (neighbours, stairways, playing } \\
\text { children, indoor dwelling noise) and } \\
\text { general traffic noise (summary of } \\
\text { parking noise, rail, road, aircraft) }\end{array}$ & $\begin{array}{l}\text { Asthma, } \\
\text { Bronchitis, } \\
\text { Respiratory symptoms (prevalence) }\end{array}$ & $\begin{array}{l}\text { Self-reported } \\
\text { doctor-diagnosed }\end{array}$ & $\begin{array}{l}\text { Cross-sec- } \\
\text { tional }\end{array}$ & 8539 & $\begin{array}{l}\text { Children and } \\
\text { adults }\end{array}$ & $\begin{array}{l}8 \text { cities in France, } \\
\text { Germany, } \\
\text { Slovakia, } \\
\text { Hungary, Spain, } \\
\text { Italy, Switzerland, } \\
\text { Lithuania }\end{array}$ & 2002-2003 \\
\hline (17) & Road traffic & Short-term & $\begin{array}{l}\text { Aggregated daily averages at } 6 \\
\text { measurement monitoring stations of } \\
\text { noise in Madrid, Leq24h, Lday (8-22h), } \\
\text { Lnight (22-8h). }\end{array}$ & $\begin{array}{l}\text { Respiratory disease hospital admission. } \\
\text { ICD-9: 144 460-519; } \\
\text { Bronchitis hospital admission. ICD-9: } \\
460-496 \\
\text { Pneumonia hospital admission. ICD-9: } \\
480-487\end{array}$ & Register & Time series & & $0-9 y$ & Madrid & $1995-2000$ \\
\hline (26) & $\begin{array}{l}\text { Annoyance to: road } \\
\text { traffic, railway, } \\
\text { aircraft, other } \\
\text { noise outside, } \\
\text { noise in or } \\
\text { around home, } \\
\text { noise in } \\
\text { apart-ment }\end{array}$ & Long-term & $\begin{array}{l}\text { ICBEN-based 11-point Likert scale noise } \\
\text { annoyance for road traffic (e.g., cars, } \\
\text { motor trucks, and tramways), flight and } \\
\text { rail traffic, other noise outside (e.g., fire } \\
\text { engines, construction sites, } \\
\text { restaurants, bars), noise in and around } \\
\text { the house, as well as noise within the } \\
\text { apartment. }\end{array}$ & Asthma (prevalence) & $\begin{array}{l}\text { Self-reported } \\
\text { doctor-diagnosed }\end{array}$ & $\begin{array}{l}\text { Cross- } \\
\text { sectional }\end{array}$ & $\begin{array}{l}336 \text { boys and } \\
316 \text { girls }\end{array}$ & $12 y$ old & Germany & 2002 \\
\hline
\end{tabular}


TABLE 1. Main characteristics of the selected studies $(n=15)$ (Continuation)

\begin{tabular}{|c|c|c|c|c|c|c|c|c|c|c|}
\hline $\begin{array}{l}\text { Refe- } \\
\text { rence }\end{array}$ & Source & $\begin{array}{l}\text { Exposure } \\
\text { length }\end{array}$ & Exposure assessment & Outcome & $\begin{array}{c}\text { Outcome } \\
\text { assessment }\end{array}$ & Design & N & Age & Study area & $\begin{array}{l}\text { Study } \\
\text { period }\end{array}$ \\
\hline (8) & Road traffic & Short-term & $\begin{array}{l}\text { Aggregated daily averages at } \\
26 \text { background measurement stations } \\
\text { of noise } 4 \mathrm{~m} \text { above ground level, Lday } \\
\text { (8-20h), Lnight (0-8h), Leq24h, } \\
\text { Lday(max), Lnight(max). } \\
\text { Fixed lags } 0 \text { to } 4 \text {. }\end{array}$ & $\begin{array}{l}\text { Respiratory disease mortality, } \\
\text { ICD-10: J00-J99. } \\
\text { Asthma mortality, ICD-10: J45-J46. } \\
\text { COPD mortality, ICD-10: J40-44, J47. } \\
\text { Pneumonia mortality, ICD-10: J12-J18 }\end{array}$ & Register & $\begin{array}{l}\text { Case-cross- } \\
\text { over }\end{array}$ & $\begin{array}{l}\text { Exposure from } \\
26 \text { locations. Total } \\
\text { observations } \\
\text { (cases) not } \\
\text { reported. } \\
\text { Mean daily cases } \\
\text { (standard } \\
\text { deviation) of } \\
\text { respiratory } \\
\text { mortality: } 18 \text { (5.2), } \\
\text { pneumonia: } \\
2.5(1.8) \text {, COPD: } \\
2.0(1.5) \text {, asthma: } \\
0.1(0.3) \text { for all } \\
\text { days of the time } \\
\text { series. }\end{array}$ & $\begin{array}{l}2 \text { groups: } \\
\quad<65 \text { and } \\
\geq 65 y\end{array}$ & Madrid & 2003-2009 \\
\hline (20) & Toad traffic & Long-term & $\begin{array}{l}\text { Individual, address level, modelled noise } \\
\text { exposure (Lday, Lnight) with a lower } \\
\text { resolution version of the } \\
\text { EU - CNOSSOS noise method, in } 3 \text { noise } \\
\text { categories (Lday: }<55,55-60, \geq 60 \mathrm{~dB} \text {; } \\
\text { Lnight: }<45,45-50, \geq 50 \mathrm{~dB} \text {. }\end{array}$ & Asthma (prevalent, incident) & Self-reported & $\begin{array}{l}\text { Cross-sec- } \\
\text { tional }\end{array}$ & 646731 & adults & $\begin{array}{r}\text { Three cohorts: } \\
\text { Norway, UK, } \\
\text { Netherlands }\end{array}$ & 2006-2013 \\
\hline (18) & Road traffic & Short-term & $\begin{array}{l}\text { Aggregated daily averages at } 27 \\
\text { background stations of noise and air } \\
\text { pollution, Lday }(7-23 \mathrm{~h}) \text {, Lnight (23h-7h), } \\
\text { Leq24h. Lags } 0 \text { to } 4 \text {. }\end{array}$ & $\begin{array}{l}\text { Respiratory causes, ICD-10: J00-J99. } \\
\text { Pneumonia, ICD-10: J12-J18. } \\
\text { COPD, ICD-10: J40-J44, J47. }\end{array}$ & Emergency call & Time series & $\begin{array}{l}\text { Exposure in } \\
27 \text { locations, } \\
108,537 \text { episodes } \\
\text { of care }\end{array}$ & & Madrid & $\begin{array}{r}\text { Jan. } 2008 \text { to } \\
\text { Dec. } 2009\end{array}$ \\
\hline (24) & $\begin{array}{l}\text { Road traffic, } \\
\text { railway }\end{array}$ & Long-term & $\begin{array}{l}\text { Neighbourhood-level percentile } 95 \text { of } \\
\text { road and railway noise levels (Lden) } \\
\text { in } 135 \text { neighbourhoods, assessed with } \\
\text { standard modelling methods }\end{array}$ & $\begin{array}{l}\text { Asthma, COPD (assessed together with } \\
\text { the Dutch ICPC-1 system codes R91, } \\
\text { R95, R96) }\end{array}$ & Register & $\begin{array}{l}\text { Cross- } \\
\text { sectional }\end{array}$ & $\begin{array}{l}\text { Exposure in } \\
135 \text { neighbour- } \\
\text { hoods, } 4450 \\
\text { residents } \\
\text { representative of } \\
\text { the Netherlands }\end{array}$ & all ages & The Netherlands & 2013 \\
\hline
\end{tabular}


TABLE 1. Main characteristics of the selected studies $(n=15)$ (Continuation)

\begin{tabular}{|c|c|c|c|c|c|c|c|c|c|c|}
\hline $\begin{array}{l}\text { Refe- } \\
\text { rence }\end{array}$ & Source & $\begin{array}{c}\text { Exposure } \\
\text { length }\end{array}$ & Exposure assessment & Outcome & $\begin{array}{l}\text { Outcome } \\
\text { assessment }\end{array}$ & Design & $\mathbf{N}$ & Age & Study area & $\begin{array}{l}\text { Study } \\
\text { period }\end{array}$ \\
\hline (6) & $\begin{array}{l}\text { Road traffic, } \\
\text { railway, aircraft, } \\
\text { transpor-tation }\end{array}$ & Long-term & $\begin{array}{l}\text { Individual, address level, modelled } \\
\text { exposure to road, railway, aircraft and } \\
\text { transportation noise (Lden). ICBEN-like } \\
\text { transportation noise annoyance } \\
\text { 11-point scale }\end{array}$ & $\begin{array}{l}9 \text { respiratory symptoms (repeated, } \\
\text { prevalent); } \\
\text { Asthma (prevalent, incident). }\end{array}$ & $\begin{array}{l}\text { Self-reported } \\
\text { doctor-diagnosed }\end{array}$ & Cohort & $\begin{array}{r}17138 \text { observations, } \\
7049 \text { participants }\end{array}$ & Adults & Switzerland & $\begin{array}{l}1991,2001 \\
2011\end{array}$ \\
\hline (19) & $\begin{array}{l}\text { Road traffic; } \\
\text { perceived road } \\
\text { traffic level }\end{array}$ & Long-term & $\begin{array}{l}\text { Individual, address level, modelled } \\
\text { exposure to road traffic noise. } \\
\text { Perceived noise question "to what } \\
\text { extent are you exposed to noise from } \\
\text { road traffic in your home neighbour- } \\
\text { hood in a 7-point Likert scale }\end{array}$ & Respiratory symptoms & Self-reported & $\begin{array}{l}\text { Cross-sec- } \\
\text { tional and } \\
\text { cohort }\end{array}$ & $\begin{array}{l}\text { Baseline: 14829; } \\
\text { Follow-up:7905 }\end{array}$ & Adults & $\begin{array}{l}\text { Dutch popula- } \\
\text { tion-based }\end{array}$ & 2011/12-2015 \\
\hline (7) & $\begin{array}{l}\text { Road traffic; } \\
\text { railway noise }\end{array}$ & Long-term & $\begin{array}{l}\text { Individual, address level, modelled traffic } \\
\text { noise (Lden) }\end{array}$ & $\begin{array}{l}\text { Respiratory disease mortality, ICD-10 } \\
\text { J00-J99. } \\
\text { COPD mortality, ICD-10 J40-J44 }\end{array}$ & Register & Cohort & 339633 & Adults & The Netherlands & 2013-2017 \\
\hline (22) & Road traffic & Long-term & $\begin{array}{l}\text { Individual, address level, modelled traffic } \\
\text { noise (Lden) }\end{array}$ & $\begin{array}{l}\text { Respiratory disease mortality. ICD-10: } \\
\text { J00-J99 }\end{array}$ & Register & Cohort & 52758 & Adults & $\begin{array}{l}\text { Copenhagen and } \\
\text { Aarhus }\end{array}$ & $1997-2016$ \\
\hline (23) & Road traffic & Long-term & $\begin{array}{l}\text { Individual, address level, modelled } \\
\text { pre- and post-natal road traffic noise }\end{array}$ & $\begin{array}{l}\text { Asthma (prevalent, incident); wheeze } \\
\text { (prevalent, incident) }\end{array}$ & $\begin{array}{l}\text { Self-reported } \\
\text { wheezing with } \\
\text { doctor-diagnosed } \\
\text { treatment }\end{array}$ & Cohort & 4000 & $\begin{array}{l}\text { From } \\
\text { pregnan-cy } \\
\text { to } 16 y\end{array}$ & Sweden & $\begin{array}{l}\text { From } \\
\text { pregnancy } \\
\text { (years } \\
\text { 1994-1996) } \\
\text { to age 16y }\end{array}$ \\
\hline (21) & Road traffic & Long-term & $\begin{array}{l}\text { Individual, address level, pre- and } \\
\text { post-natal road traffic noise assigned } \\
\text { from EU noise maps ( } 5 \text { cohorts) or } \\
\text { measurements (1 cohort) } \\
\text { in } 4 \text { categories. }\end{array}$ & $\begin{array}{l}\text { Forced expiratory volume in } 1 \text { second } \\
\text { percent predicted values }\left(\mathrm{FEV}_{1} \%\right)\end{array}$ & $\begin{array}{l}\text { Spirometry by } \\
\text { trained technician } \\
\text { using standard } \\
\text { protocols }\end{array}$ & Cohort & $\begin{array}{l}1033(29-30 \% \text { missing } \\
\text { for noise } \\
\text { exposure, imputed) }\end{array}$ & 6 to $12 y$ & $\begin{array}{l}\text { Cohorts in France, } \\
\text { Greece, } \\
\text { Lithuania, } \\
\text { Norway, Spain, } \\
\text { and the UK }\end{array}$ & $\begin{array}{l}\text { Children } \\
\text { born } \\
\text { between } \\
2003 \text { and } \\
2009\end{array}$ \\
\hline
\end{tabular}

COPD: chronic obstructive obstructive disease 
TABLE 2. Main results of the selected studies $(n=15)$

\begin{tabular}{|c|c|c|c|c|c|c|c|c|}
\hline $\begin{array}{l}\text { Refe- } \\
\text { rence }\end{array}$ & Source & $\begin{array}{c}\text { Exposure } \\
\text { length }\end{array}$ & Outcome & Design & $\mathbf{N}$ & Age & Main adjustments & Quantitative results \\
\hline (16) & Road traffic & Short-term & $\begin{array}{l}\text { Respiratory causes } \\
\text { (hospital } \\
\text { admission). ICD9 } \\
460-459\end{array}$ & Time series & $\begin{array}{l}\text { Exposure in } \\
6 \text { locations, } \\
1096 \\
\text { observations }\end{array}$ & Adults & $\begin{array}{l}\text { Temperature, humidity, influenza } \\
\text { epidemics, yearly trends, } \\
\text { seasonality and weekly trends, } \\
\text { air pollution. }\end{array}$ & $\begin{array}{l}\text { RR (95\% Cl): } 1.038 \text { (1.011; 1.067) per } 1 \mathrm{~dB} \text { of L24h, in current day (Poisson regression model). } \\
\text { Associations for lags } 1 \text { to } 4 \text { not shown. }\end{array}$ \\
\hline (10) & Traffic emissions & Long-term & $\begin{array}{l}\text { Bronchitis } \\
\text { (prevalence) }\end{array}$ & $\begin{array}{l}\text { Cross- } \\
\text { sectional }\end{array}$ & 68 & Children & $\begin{array}{l}\text { age, sex, smoking, parental } \\
\text { educational level. } \\
\text { No multi-exposure models. }\end{array}$ & $\begin{array}{l}\text { There was a dose-dependent association between increasing traffic emissions and annual } \\
\text { physician contacts due to bronchitis. Compared to low traffic emission category: high } \\
\text { emission: } \beta(95 \% \mathrm{CI}): 2.60(1.47 ; 3.72) \text { increase in annual physician contacts due to } \\
\text { bronchitis. } \\
\text { Night-time noise exposure was associated with increased morning cortisol. No association } \\
\text { reported between noise and bronchitis. }\end{array}$ \\
\hline (25) & $\begin{array}{l}\text { Neighbour-hood } \\
\text { annoyance; } \\
\text { Transportation } \\
\text { annoyance. }\end{array}$ & Long-term & $\begin{array}{l}\text { Asthma, } \\
\text { Bronchitis, } \\
\text { Respiratory } \\
\text { symptoms } \\
\text { (prevalence) }\end{array}$ & $\begin{array}{l}\text { Cross- } \\
\text { sectional }\end{array}$ & 8539 & $\begin{array}{l}\text { Children } \\
\text { and } \\
\text { adults }\end{array}$ & $\begin{array}{l}\text { age, sex and city (basic block), } \\
\text { socioeconomic state (block 2) } \\
\text { and alcohol consumption, body } \\
\text { mass index, tobacco usage, } \\
\text { physical activity (block 3), } \\
\text { housing conditions (block 4). }\end{array}$ & 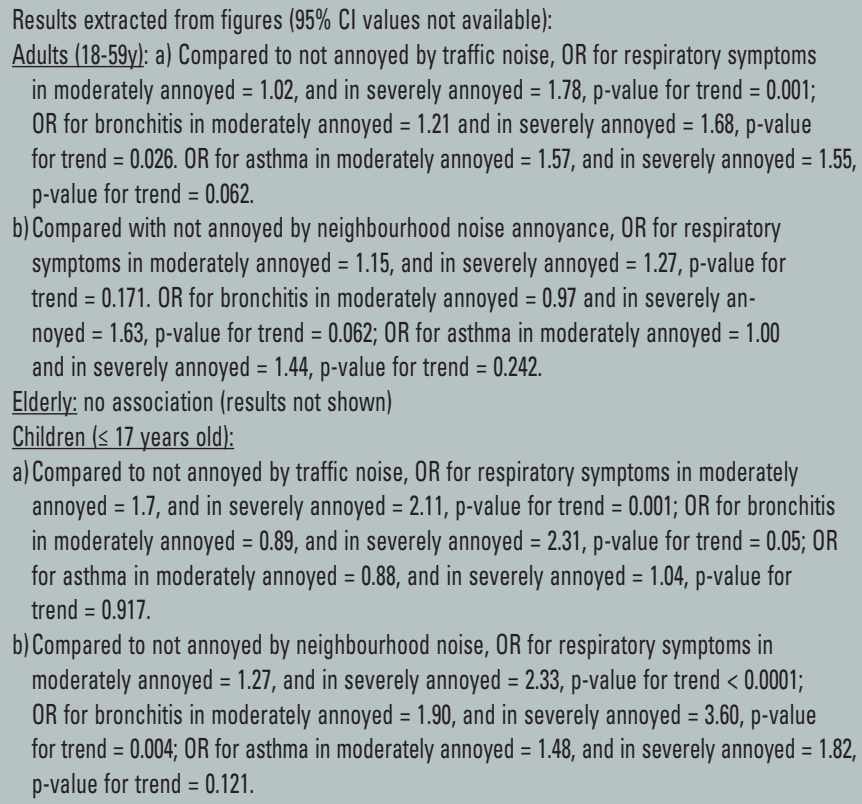 \\
\hline
\end{tabular}


TABLE 2. Main results of the selected studies $(n=15)$ (Continuation)

\begin{tabular}{|c|c|c|c|c|c|c|c|c|}
\hline $\begin{array}{l}\text { Refe- } \\
\text { rence }\end{array}$ & Source & $\begin{array}{l}\text { Exposure } \\
\text { length }\end{array}$ & Outcome & Design & $\mathbf{N}$ & Age & Main adjustments & Quantitative results \\
\hline (17) & Road traffic & short-term & $\begin{array}{l}\text { Respiratory disease } \\
\text { hospital } \\
\text { admission. ICD-9: } \\
\text { 144 460-519; } \\
\text { Bronchitis hospital } \\
\text { admission. ICD-9: } \\
\text { 460-496 } \\
\text { Pneumonia hospital } \\
\text { admission. ICD-9: } \\
\text { 480-487 }\end{array}$ & time series & & $0-9 y$ & $\begin{array}{l}\text { Adjustment for meteorological } \\
\text { variables. It seems that there } \\
\text { was no mutual adjustment for } \\
\text { air poll and noise due } \\
\text { to collinearity. }\end{array}$ & $\begin{array}{l}\text { RR (95\% Cl) for respiratory causes: } 1.05(1.01 ; 1.08) \text { per } 1 \mathrm{~dB} \text {, at lag } 3 \text { of LAeq24h; RR for } \\
\text { pneumonia: } 1.08 \text { (1.02; } 1.15) \text { at lag } 3 \text { of LAeq24h. } \\
\text { RR for bronchitis and other lags: not shown (only statistically significant associations are } \\
\text { reported). Number of studied lags not reported. }\end{array}$ \\
\hline (26) & $\begin{array}{l}\text { Road traffic, } \\
\text { railway, aircraft, } \\
\text { other noise } \\
\text { outside, noise } \\
\text { in or around } \\
\text { home, noise in } \\
\text { apart-ment }\end{array}$ & Long-term & Asthma (prevalence) & $\begin{array}{l}\text { Cross- } \\
\text { sectional }\end{array}$ & $\begin{array}{l}336 \text { boys and } 316 \\
\text { girls }\end{array}$ & $12 y$ old & $\begin{array}{l}\text { Study centre, maternal school } \\
\text { education, parental history of } \\
\text { allergy, and presence of older } \\
\text { siblings as potential } \\
\text { confounding variables }\end{array}$ & 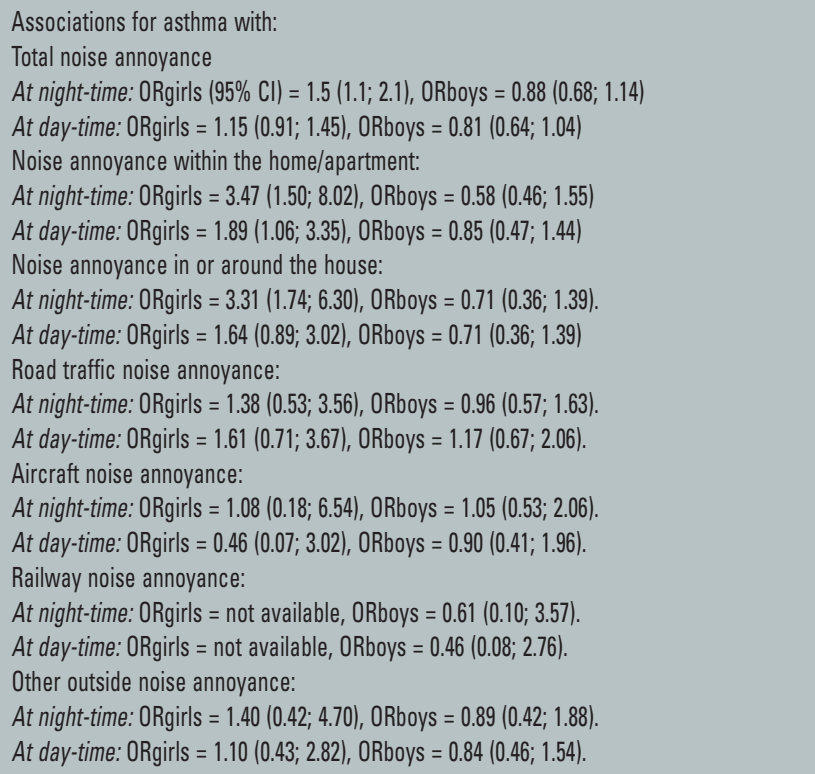 \\
\hline
\end{tabular}


TABLE 2. Main results of the selected studies $(n=15)$ (Continuation)

\begin{tabular}{|c|c|c|c|c|c|c|c|c|}
\hline $\begin{array}{l}\text { Refe- } \\
\text { rence }\end{array}$ & Source & $\begin{array}{l}\text { Exposure } \\
\text { length }\end{array}$ & Outcome & Design & $\mathbf{N}$ & Age & Main adjustments & Quantitative results \\
\hline (8) & Road traffic & Short-term & $\begin{array}{l}\text { Respiratory disease } \\
\text { mortality, ICD-10: } \\
\text { J00--J99. } \\
\text { Asthma mortality, } \\
\text { ICD-10: J45-J46. } \\
\text { COPD mortality, } \\
\text { ICD-10: J40-44, } \\
\text { J47. } \\
\text { Pneumonia } \\
\text { mortality, ICD-10: } \\
\text { J12-J18 }\end{array}$ & Case-crossover & $\begin{array}{l}\text { Exposure from } \\
26 \text { locations. } \\
\text { Total } \\
\text { observations } \\
\text { (cases) not } \\
\text { reported. } \\
\text { Mean daily } \\
\text { cases } \\
\text { (standard } \\
\text { deviation) } \\
\text { of respiratory } \\
\text { mortality: } \\
18(5.2) \text {, } \\
\text { pneumonia: } 2.5 \\
\text { (1.8), COPD: } \\
2.0(1.5) \text {, } \\
\text { asthma: } 0.1 \\
\text { (0.3) for all } \\
\text { days of the } \\
\text { time series. }\end{array}$ & $\begin{array}{l}2 \text { groups: } \\
<65 \\
\text { and } \\
\geq 65 y\end{array}$ & $\begin{array}{l}\mathrm{PM} 2.5, \mathrm{NO}_{2} \text {, mean temperature } \\
\text { and relative humidity }\end{array}$ & 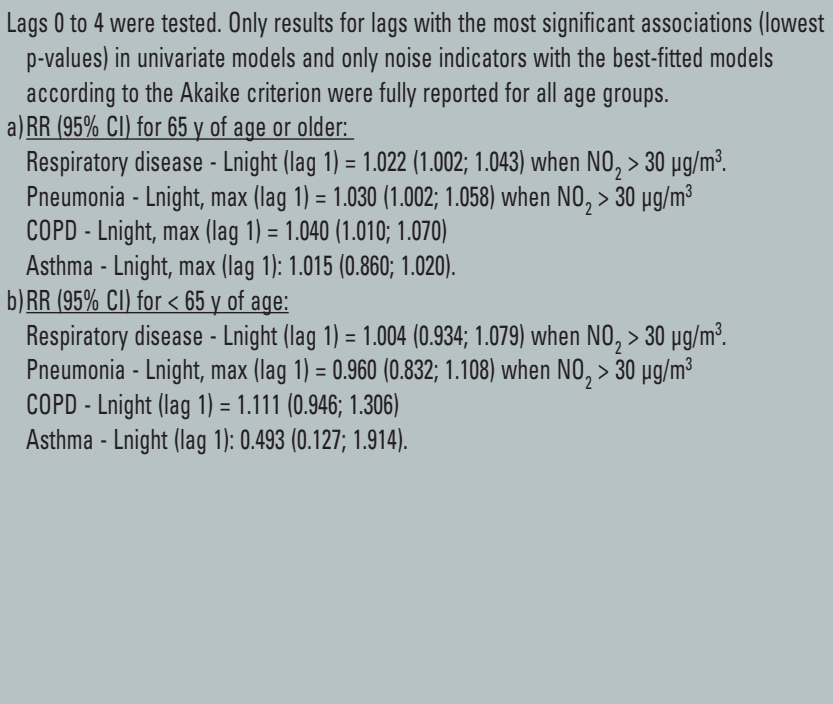 \\
\hline (20) & Road traffic & Long-term & $\begin{array}{l}\text { Asthma (prevalent, } \\
\text { incident) }\end{array}$ & $\begin{array}{l}\text { Cross- } \\
\text { sectional }\end{array}$ & 646731 & Adults & $\begin{array}{l}\text { Adjusted for study, sex, age, } \\
\text { education, employment status, } \\
\text { smoking status and body mass } \\
\text { index and } \mathrm{PM}_{10} \text { or } \mathrm{NO}_{2}\end{array}$ & $\begin{array}{l}\text { OR (95\% CI) in single-exposure models of Lnight (Ref. }<45 \mathrm{~dB}) \text { with ever-had asthma: } \\
45-50 \mathrm{~dB}=0.991(0.973 ; 1.009), \geq 50=1.014(0.988 ; 1.041) \text {. } \\
\mathrm{OR}(95 \% \mathrm{CI}) \text { in single-exposure models of Lnight (Ref. }<45 \mathrm{~dB}) \text { with current asthma: } \\
\quad 45-50 \mathrm{~dB}=1.001(0.973 ; 1.031), \geq 50=1.010(0.970 ; 1.053) \text {. } \\
\text { Results were similar for Lday and after adjustment for } \mathrm{PM}_{10} \text { or } \mathrm{NO}_{2} \text {. }\end{array}$ \\
\hline (18) & Road traffic & Short-term & $\begin{array}{l}\text { Respiratory causes, } \\
\text { ICD-10: J00-J99. } \\
\text { Pneumonia, ICD-10: } \\
\text { J12-J18. } \\
\text { COPD, ICD-10: } \\
\text { J40-J44, J47. }\end{array}$ & Time series & $\begin{array}{l}\text { Exposure in } \\
27 \text { locations, } \\
108,537 \\
\text { episodes } \\
\text { of care }\end{array}$ & & Air pollutants and temperature & $\begin{array}{l}\text { Lnight (lag 0) with daily respiratory medical calls: RR (95\% CI): } 1.14(1.11 ; 1.18) \text { per } 1 \mathrm{~dB} \text {. } \\
\text { Lnight (lag 0, 1) with COPD medical calls: RR (95\% CI): } 1.15(1.09 ; 1.21) \text { per } 1 \mathrm{~dB} \\
\text { Lnight (lag 0) registered the highest RR for calls due to pneumonia RR }=1.17(95 \% \mathrm{Cl} \text { : } \\
\text { 1.09; 1.25) per } 1 \mathrm{~dB} \text {. } \\
\text { No associations observed for Lday, or for lags } 2 \text { to } 4 \text { (results not shown). }\end{array}$ \\
\hline
\end{tabular}


TABLE 2. Main results of the selected studies $(n=15)$ (Continuation)

\begin{tabular}{|c|c|c|c|c|c|c|c|c|}
\hline $\begin{array}{l}\text { Refe- } \\
\text { rence }\end{array}$ & Source & $\begin{array}{l}\text { Exposure } \\
\text { length }\end{array}$ & Outcome & Design & $\mathbf{N}$ & Age & Main adjustments & Quantitative results \\
\hline (24) & $\begin{array}{l}\text { Road traffic, } \\
\text { railway }\end{array}$ & Long-term & $\begin{array}{l}\text { Asthma, COPD } \\
\text { (assessed } \\
\text { together with the } \\
\text { Dutch ICPC-1 } \\
\text { system codes R91, } \\
\text { R95, R96) }\end{array}$ & $\begin{array}{l}\text { Cross- } \\
\text { sectional }\end{array}$ & $\begin{array}{l}\text { Exposure in } \\
135 \text { neigh- } \\
\text { bourhoods, } \\
4450 \text { residents } \\
\text { representative } \\
\text { of the } \\
\text { Netherlands }\end{array}$ & all ages & $\begin{array}{l}\text { Adjusted for sex, age } \\
\text { (continuous), household } \\
\text { income and socio-economic } \\
\text { status (individual level) and } \\
\text { municipality and neighbourhood } \\
\text { (group level). No multi-expo } \\
\text { models }\end{array}$ & $\begin{array}{l}\text { OR (95\% Cl) road Lden: } 0.98(95 \% \text { Cl: 0.69; 1.38) per } 10 \mathrm{~dB} \text {; railway Lden: } 1.01(0.87 ; 1.17) \\
\text { per } 10 \mathrm{~dB}\end{array}$ \\
\hline (6) & $\begin{array}{l}\text { Road traffic, } \\
\text { railway, aircraft, } \\
\text { transpor-tation }\end{array}$ & Long-term & $\begin{array}{l}9 \text { respiratory } \\
\text { symptoms } \\
\text { (repeated, } \\
\text { prevalent); } \\
\text { Asthma (prevalent, } \\
\text { incident). }\end{array}$ & Cohort & $\begin{array}{l}17138 \\
\text { observations, } \\
7049 \\
\text { participants }\end{array}$ & Adults & $\begin{array}{l}\text { Common adjustments plus air } \\
\text { pollution } \mathrm{PM}_{10} \text { and mutual } \\
\text { adjustment for noise } \\
\text { annoyance } \\
\text { or noise level }\end{array}$ & 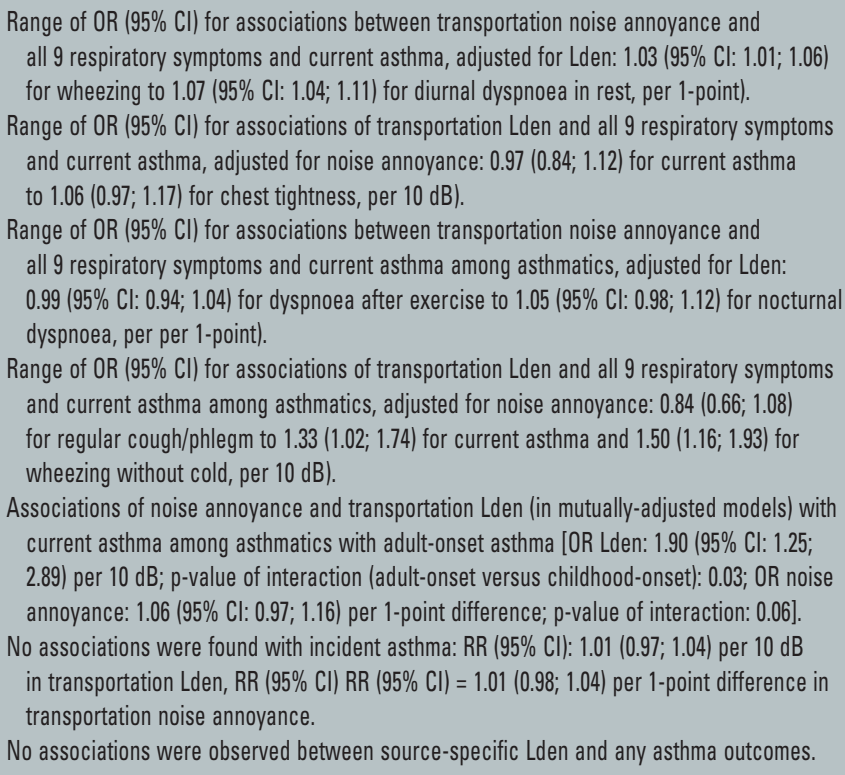 \\
\hline (19) & $\begin{array}{l}\text { Road traffic; } \\
\text { perceived road } \\
\text { traffic level }\end{array}$ & Long-term & $\begin{array}{l}\text { Respiratory } \\
\text { symptoms }\end{array}$ & $\begin{array}{l}\text { Cross- } \\
\text { sectional and } \\
\text { cohort }\end{array}$ & $\begin{array}{l}\text { Baseline: 14829; } \\
\text { Follow-up: } \\
7905\end{array}$ & adults & $\begin{array}{l}\text { Adjusted for baseline values of } \\
\text { sex, age, education, smoking, } \\
\text { socioeconomic position, and } \\
\text { year (baseline/follow-up). Also } \\
\text { mutual adjustment for } \\
\text { perception or modelled level. } \\
\text { No multi-exposure models } \\
\text { including air pol, noise, RMF }\end{array}$ & $\begin{array}{l}\text { Perceived noise exposure before and after adjustment for modelled road traffic noise level: } \\
\beta(95 \% \mathrm{Cl}): 0.04(0.03 ; 0.05) \text { per } 1 \text { point. For modelled road noise levels: } \beta(95 \% \mathrm{Cl}): 0.00 \\
(0.00 ; 0.01) \text { per } 1 \mathrm{~dB}, \mathrm{p} \text {-value }=0.02 \text {, after adjustment for perceived noise, }-0.00(-0.00 ; 0.00) \\
\text { per } 1 \mathrm{~dB}, \mathrm{p} \text {-value }=0.655\end{array}$ \\
\hline
\end{tabular}


TABLE 2. Main results of the selected studies $(n=15)$ (Continuation)

\begin{tabular}{|c|c|c|c|c|c|c|c|c|}
\hline $\begin{array}{l}\text { Refe- } \\
\text { rence }\end{array}$ & Source & $\begin{array}{l}\text { Exposure } \\
\text { length }\end{array}$ & Outcome & Design & $\mathbf{N}$ & Age & Main adjustments & Quantitative results \\
\hline (7) & $\begin{array}{l}\text { Road traffic; } \\
\text { railway noise }\end{array}$ & Long-term & $\begin{array}{l}\text { Respiratory disease } \\
\text { mortality, ICD-10 } \\
\text { J00-J99. } \\
\text { COPD mortality, } \\
\text { ICD-10 J40-J44 }\end{array}$ & Cohort & 339633 & Adults & $\begin{array}{l}\text { Age, sex, SES, lifestyles; } \\
\text { multi-exposure models = result }\end{array}$ & $\begin{array}{l}\text { Road Lden - Respiratory mortality: } \\
\text { HR = } 0.85 \text { (95\% Cl: } 0.90 ; 1.00) \text { per IQR in Lden levels (7.40 dB). } \\
\text { COPD mortality: HR (95\% CI): } 0.98 \text { (0.91; 1.05) per IOR in Lden levels (7.40 dB). } \\
\text { Railway noise - Respiratory mortality: HR = } 1.03 \text { (95\% CI: } 0.98 ; 1.09) \text { per IQR in Lden levels } \\
\text { (8.60 dB). } \\
\text { COPD mortality: HR (95\% CI): } 1.03 \text { (0.96; 1.10) per IQR in Lden levels (8.60 dB). }\end{array}$ \\
\hline (22) & Road traffic & Long-term & $\begin{array}{l}\text { Respiratory disease } \\
\text { mortality. ICD-10: } \\
\text { J00-J99 }\end{array}$ & Cohort & 52758 & Adults & $\begin{array}{l}\text { Age, sex, SES, lifestyles, common } \\
\text { adjustment + PM2.5 and } \mathrm{NO}_{2}\end{array}$ & $\begin{array}{l}\text { Null associations between road traffic Lden and respiratory disease. At most exposed facade } \\
\text { for } 5 \text {-year mean exposure: } \mathrm{HR}=1.03(0.97 ; 1.09) \text { per IOR in Lden }(10.4 \mathrm{~dB}) \text {. After adjustment } \\
\text { for } \mathrm{NO}: \mathrm{HR}=1.04(0.97 ; 1.12) \text { per IOR in Lden }(10.4 \mathrm{~dB}) \text {. At least exposed facade for } 5 \text {-year } \\
\text { mean exposure: } \mathrm{HR}=1.04(0.98 ; 1.10) \text { per IQR in } \mathrm{Lden}(8.4 \mathrm{~dB}) \text {. After adjustment for } \mathrm{NO}_{2} \text { : } \\
\mathrm{HR}=1.04(0.98 ; 1.10) \text { per IQR in Lden }(8.4 \mathrm{~dB}) \text {. Results had similar magnitude of estimated } \\
\text { effects for 1-year and 10-year noise exposure windows. }\end{array}$ \\
\hline (23) & Road traffic & Long-term & $\begin{array}{l}\text { Asthma (prevalent, } \\
\text { incident); wheeze } \\
\text { (prevalent, } \\
\text { incident) }\end{array}$ & Cohort & 4000 & $\begin{array}{l}\text { From } \\
\text { preg- } \\
\text { nan-cy } \\
\text { to } 16 y\end{array}$ & $\begin{array}{l}\text { Sex, maternal smoking, SES } \\
\text { at individual and area level } \\
\text { and air pollution }\end{array}$ & $\begin{array}{l}\text { Non-significant associations for asthma ever up to } 16 \text { years with residential road traffic noise } \\
\text { exposure in infancy } \geq 55 \mathrm{~dB}: 0 \mathrm{OR}=1.22 ; 95 \% \mathrm{Cl}: 0.90 ; 1.65 \text { ) per } 10 \mathrm{~dB} \text {. No quantitative result } \\
\text { provided for incident asthma (only figure - null associations). } \\
\text { No quantitative results provided for wheeze (only figure - null associations) }\end{array}$ \\
\hline (21) & Road traffic & Long-term & $\begin{array}{l}\text { Forced expiratory } \\
\text { volume in } \\
1 \text { second percent } \\
\text { predicted values } \\
\left(\mathrm{FEV}_{1} \%\right)\end{array}$ & Cohort & $\begin{array}{l}1033(29-30 \% \\
\text { missing for } \\
\text { noise } \\
\text { exposure, } \\
\text { imputed) }\end{array}$ & 6 to $12 y$ & $\begin{array}{l}\text { Centre of recruitment, child's sex, } \\
\text { age, height and parental } \\
\text { country of birth, breastfeeding } \\
\text { duration, season of conception, } \\
\text { presence of older siblings, } \\
\text { parental education level, } \\
\text { maternal age, maternal } \\
\text { pre-pregnancy body-mass } \\
\text { index (BMI), postnatal passive } \\
\text { smoking status, and prenatal } \\
\text { maternal active and passive } \\
\text { smoking status. Also } \\
\text { adjustment for confounding } \\
\text { by co-exposures. }\end{array}$ & $\begin{array}{l}\text { No associations observed with } \mathrm{FEV}_{1} \% \text {. } \\
\beta \text { (95\% CI) from ExWAS: } \\
\text { Prenatal Lden at home (Ref. }<55 \mathrm{~dB}): 55-60 \mathrm{~dB}=1.5(-1 ; 3.9) ; \\
60-65 \mathrm{~dB}=1.4(-1.4 ; 4.1) ;>65 \mathrm{~dB}=0.2(-2.7 ; 3.1) \\
\text { Postnatal Lnight at home: (Ref. }<57) ; 57-67=0.1 \\
(-2.8 ; 3.0) ; 67-71 \mathrm{~dB}=2.3 \\
(-1.9 ; 6.4) ;>71 \mathrm{~dB}=1.5(-3.7 ; 6.7) \\
\text { Results were similar for noise at school and post-natal Lden. }\end{array}$ \\
\hline
\end{tabular}

COPD: chronic obstructive pulmonary disease; $\mathrm{FEV}_{1}$ : forced expiratory volume in one second. 